\title{
STUDI SERAPAN ION SENG(II) OLEH BIOMASSA MIKROALGA (Tetraselmis chuii)
}

\author{
Bahrizal dan Rahadian Z \\ Staf pengajar Jurusan Kimia FMIPA UNP
}

\begin{abstract}
In the present work, the process of zinc-ion adsorption by $T$. chuii biomass have been investigated. This investigation intend to determinate capacity of adsorption the biomass for zinc-ion in water. A weight of $100 \mathrm{mg}$ biomass was put into $6 \mathrm{ppm}$ of the metal-ion solution whose $\mathrm{pH}$ varied from 5.0 to 7.0. Then, these solutions were stirred for 30 minutes. After filtering, the metal-ion concentration in the filtrate was determined by atomic absorption spectrometry. The amount of ion adsorbed by the biomass was taken as the difference between the initial and final concentration of the solution. Further, the same method was carried out to the varied concentration. The result showed, the optimum $\mathrm{pH}$ for metal-ion adsorption by the biomass is 5.5 , having adsorption value $1.106 \mathrm{mg} / \mathrm{g}$. Capacity of zinc-ion adsorption was obtained by varied concentration, yielded value of $3.557 \mathrm{mg} / \mathrm{g}$.
\end{abstract}

Keywords : T. chuii, biomass, adsorption, spectrometry

\section{DAFTAR PUSTAKA}

1. Harrison, Environmental Analysis Using Chromatogaphy With Atomic Spectroscopy, Ellis Horwood Limited, Chichester, 1989.

2. P. O. Harris, and G. J. Ramelow, Binding of Metal Ions by Particulate Biomass Derived from Chlorella Vulgaris and Scenedesmus Quadricauda, Environ. Sci. Technol., 24: 220-228, (1990).

3. C. A. Mahan, and J. A. Holcombe, Immobilization of Algae Cells on Silica Gel and Their Characterization Trace Metal Preconcentration, Anal. Chem., 64(17): 1933-1939, (1992).

4. E. Torres, A. Cid, C. Herrero, and J. Abalde, Removal of Cadmium Ions by The Marine Diatom Phaeodactylum Tricornutum Bohlin Accumulation and Long-Term Kinetics of Uptake, Bioresource Technology, 63:213-220, (1998).

5. J. L. Zhou, P. L. Huang, and R. G. Lin, Sorption and Desorption of $\mathrm{Cu}$ and
Cd by Macroalgae and Microalgae, Environ. Pollut., 101: 67-75, (1998).

6. B. Greene, M. Hosea, R. McPherson, M. Henzi. M. D. Alexander, and D. W. Darnall, Interaction of Gold(I) and Gold(III) Complexes with Algal Biomass, Environ. Sci. Technol., 20(6): 627-632. (1986).

7. A. Isnansetyo dan Kurniastuti, Teknik Kultur Phytoplankton \& Zooplankton, Kanisius, Yogyakarta, 1995.

8. D.W. Darnall, B. Greene, M. T. Henzy, J. M Hosea, R. A. McPherson, J. Sneddon, and M. D. Alexander, Selective Recovery of Gold and Other Metal Ions from Algal Biomass, Environ. Sci. Technol., 20(2): 206-208, (1986).

9. Y. Zhao, Y. Hao, and G. J. Ramelow, Evaluation of Treatment Techniques for Increasing The Uptake Metal Ions From Solution by Nonliving Seaweed Algal Biomass, Environ. Mon. and Ass., 33: 6170, (1994).

10. U. S. Ramelow, C. N Guidry, and S.D Fisk, A kinetic study of metal ion binding by biomass immobilized in polymers, $J$. of Hazard. Mat., 46: 37-55, (1996).

11. Bahrizal, Pengikatan IonCu(II), Cr(VI), Mn(II) dan Mo(VI) oleh Chaetoceros 
Calcitran, Tesis Pascasarjana S-2, UGM, Yogyakarta, 1997.

12. I. A. H. Schneider dan J. Rubio, Sorption of Heavy Metal Ions by the Nonliving Biomass of Freshwater Macrophytes, Environ. Sci. Technol., 33: 2213-2217, (1999).

13. B. Cordero, P. Lodeiro, R. Herrero, and M. E. S. Vicente, Biosorption of
Cadmium by Fucus spiralis, Environ. Chem., 180-187, (2004).

14. W. M. Antunes, A. S. Luna, C. A. Henriques and A.C. Costa, An evaluation of copper biosorption by a brown seaweed under optimized conditions, Electronic Journal of Biotechnology, 6(3): 174-184, (2003). 